Innesa Topala

http://dx.doi.org/10.18778/8088-635-3.12

\title{
Tożsamość regionalna mieszkańców Donbasu
}

\begin{abstract}
Artykut analizuje tożsamość regionalną mieszkańców Donbasu. Autorka wyjaśnia, w jaki sposób wspólne doświadczenia społeczne, wartości i podobny styl życia ukształtowały społeczeństwo i zadecydowały o silnym poczuciu przynależności do wspólnoty, opartej na wspólnym terytorium, na omawianym obszarze. Poruszony zostaje problem oligarchicznego modelu zarządzania, który opóźnit rozwój społeczeństwa obywatelskiego, a także kwestia nierówności społecznych, która doprowadzita do rozwoju relacji patron-klient. Wyjaśnia też, jak liczne mity i stereotypy o Donbasie zakorzenione w świadomości ludzi i wykorzystywane przez różnych polityków, przyczyniają się do eskalacji konfliktu między wschodnią i zachodnią częścią Ukrainy.
\end{abstract}

Słowa kluczowe: tożsamość regionalna, Donbas, Ukraina, zjawisko migracji, internacjonalizm, mity i stereotypy

Donbaski separatyzm jest bardzo aktualnym i ważnym tematem do dyskusji nie tylko na Ukrainie, czy w Rosji, ale i w kontekście ogólnoeuropejskim, a nawet globalnym. W poniższym artykule nakreślę podłoże i specyfikę tożsamości mieszkańców tego regionu, starając się jej nie krytykować, ani nie osądzać oraz mając nadzieję, że zrozumienie racji obu stron konfliktu jest ważną drogą ku jego zażegnaniu.

Donbas jest regionem znajdującym się we wschodniej części Ukrainy. Możemy mówić o małym (obwody doniecki i ługański) i o dużym Donbasie (część ziem: charkowskiej, dniepropietrowskiej, zaporoskiej i rostowskiej). W języku potocznym określenie „Donbas” jest częściej używane w odniesieniu do obwodów donieckiego i ługańskiego.

Różnice w kulturze i mentalności, widoczne pomiędzy mieszkańcami Donbasu i większością społeczeństwa Ukrainy są spowodowane głównie przez czynniki historyczne, etniczne i regionalne. Społeczne i kulturowe różnice 
między wschodem i zachodem Ukrainy związane są z historią ról, jakie Europa Zachodnia i Rosja odgrywały, względnie chciały odgrywać, w rozwoju polityczno-gospodarczym i kulturalnym obszarów, które składają się na współczesną Ukrainę.

Dzikie Pola w XV i XVI wieku przyciągały rzesze ludności z różnych części Europy Wschodniej oraz z Azji. Ziemia niczyja symbolizowała wolność i swoiste miejsce schronienia dla tych, którzy pragnęli wyzwolić się od prześladowań i różnych form wyzysku. Na ówczesnych ziemiach Donbasu zamieszkiwały liczne grupy ludności, co było powodem nieustannych walk międzyetnicznych. Dzikie Pola zrodziły m.in. Kozaków. W XVII w. ziemie Donbasu zostały najpierw zasiedlone przez Kozaków zaporoskich, a następnie Kozaków dońskich. Ich styl życia, pełen wolności, ale także brutalny, przyczynił się do powstania mitu o dzikim i niekontrolowanym terytorium ${ }^{1}$.

Również wejście wspomnianych ziem w drugiej połowie XVII w. w skład imperium rosyjskiego nie ukróciło wśród mieszkańców sąsiadujących z nimi obszarów obaw przed kozacką hardością i wojowniczością. Kozacy dońscy uzyskali autonomię, natomiast struktury wojskowe Kozaków zaporoskich zostały zlikwidowane. Po wprowadzeniu w Donbasie poddaństwa „wolne pola” straciły swój status, przetrwały jednak w postaci mitu, który jeszcze przez długi czas przyciągał ludzi na omawiane tereny.

Na początku XIX wieku pojawiają się pierwsze kopalnie. W 1795 roku Katarzyna II wydaje zezwolenie na budowę huty i w tym samym roku Charles Gascoigne, inżynier pochodzenia brytyjskiego, zaczyna jej budowę. Wieś, jaką utworzono wokół huty, otrzymała nazwę Ługańsk. W 1869 roku John Hughes (Walijczyk) rozpoczął budowę pierwszej huty w miejscowości Juzowka (nazwa pochodzi od nazwiska założyciela). Jest to jednocześnie data założenia Doniecka, który w roku 1927 przyjął nazwę Stalino, a w 1960 - Donieck. Kapitał zagraniczny stanowił znaczącą część środków zasilających rozwój przemysłowy Donbasu. Pierwsi założyciele kopalń oraz hut byli cudzoziemcami i to właśnie oni jeszcze przez długi czas sprawowali władzę w nich oraz $w$ otaczających je miejscowościach ${ }^{2}$.

Możliwość pracy przyciągała duże rzesze ludzi z całego imperium. Zjawisko migracji stało się tym samym nieodłącznym elementem historii Donbasu. Rozwojowi regionu towarzyszyła wielokulturowość. Donbas często stawał się także miejscem ostoi dla kryminalistów i nowym domem dla tych, których rząd nie tolerował. Procesy etniczne w Donbasie, zachodzące na przełomie XIX i XX wieku,

\footnotetext{
${ }^{1}$ Г. Куромія, Свобода і терор на Донбасі Украӥнсько-російське прикордоння, 1870-1990-ті роки, thum. Г. Корян, А. Агеєв, Київ 2002, s. 510.

${ }^{2}$ M. Studenna-Skrukwa, Ukraiński Donbas, Poznań 2014, s. 307.
} 
można porównać ze zjawiskiem melting pot. Polegało ono na tym, że ludzi znajdujących się w oderwaniu od swoich narodowych korzeni łączyła i niejako upodobniała do siebie tożsamość regionalna. Narodziła się ona $\mathrm{z}$ niemalże identycznych doświadczeń: migracji, ciężkiej pracy w hutach i kopalniach, a także konieczności podporządkowania, rodzącej nienawiść do właścicieli ziemskich, oraz wspólnej walki o sprawiedliwość. Według spisu ludności z 1897 roku w Donbasie zamieszkiwali: Małorusini (Ukraińcy) (52,4\%), Rosjanie (28,7\%), Grecy $(6,4 \%)$, Niemcy $(4,2 \%)$, Żydzi (2,9\%), Tatarzy (2,1\%), Białorusini $(0,8 \%)$, Polacy $(0,4 \%)$ oraz Kozacy dońscy ${ }^{3}$. Dominował język ukraiński i surżyk, powstały z połączenia języka rosyjskiego i ukraińskiego.

Podobny tryb życia, wspólna praca, dzielone radości i smutki dnia codziennego sprzyjały rozwijaniu się internacjonalizmu. U podstaw rozwoju Donbasu leży głównie ekonomia, a nie jak powszechnie się uważa „czynnik etniczny”. To właśnie robotnicy (w tym górnicy i metalurdzy) byli na tych terenach klasą dominującą liczebnie.

Trudne warunki życia, związane głównie z ubóstwem, bezwzględnym wyzyskiem i zagrożeniami, jakie niosła ze sobą praca górników i hutników spowodowały, iż proces rozwoju Donbasu można porównać do rozwoju Dzikiego Zachodu, pozbawionego jakichkolwiek zasad dobrego współżycia w wymiarze społecznokulturowym. Ludzie, którzy na ziemiach Donbasu szukali wolności od represji politycznych i ekonomicznych, poczuli się oszukani. Zaczęły się protesty i powstania robotników przeciwko właścicielom i ekonomicznej niesprawiedliwości. Każdy protest kończył się śmiertelnymi ofiarami i nałożeniem kar na resztę robotników.

W przeciwieństwie do europejskich doświadczeń w tworzeniu struktury społeczeństwa obywatelskiego w Donbasie miały one zupełnie odmienny charakter. Ciężka praca fizyczna, ciągłe poczucie zagrożenia, prymitywny styl życia - różnił się i do tej pory różni się zasadniczo od zachodniego. Wynika to również z faktu, że przez długi okres czasu największe miasto tego regionu było własnością firmy Hughesa. Firma rządziła całością ziemi, wszystkimi jej zasobami (w tym mieszkaniowymi), a wszelka działalność handlowa była możliwa tylko za zgodą kierowanej przez nią instytucji o nazwie Noworosyjskie Stowarzyszenie Przemysłu Węglowego, Żelaznego i Kolejowego. To właśnie wspomniana organizacja, a nie obywatele miasta, regulowała wszystkie aspekty np. usług komunalnych, od organizacji handlu do sprzątania śmieci i dostarczania węgla włącznie. Ludność nie brała udziału w działalności publicznej, nie miała także wpływu na wybór władz. Naturalną konsekwencją był brak poczucia

\footnotetext{
${ }^{3}$ Г. Куромія, dz. cyt., s. 510.
} 
przynależności do miasta, odpowiedzialności za nie, co sprzyjało powstawaniu problemów w utrzymaniu ogólnego porządku.

Mieszkańcy Donbasu nie stworzyli społeczeństwa obywatelskiego, odpowiedzialnego za swój los i za los regionu. Osoby przybywające tam zwykle szybko asymilowały się, zapominając o swym etnicznym i społecznym pochodzeniu. Człowiek stawał się jednym z wielu trybików w skomplikowanej machinie systemu, co sprzyjało postrzeganiu świata w sposób ujednolicony i bezrefleksyjny. Początkowo kult silnego przemysłu przesłaniał wszystkie inne cele i wartości. Fabryczny mikroświat promował hasła, zastępcze wobec wszelkich wcześniej funkcjonujących na tym obszarze mitów, legend ludowych i ideałów. Wszystko to stworzyło pewną społeczno-psychologiczną atmosferę, w której odbywało się tworzenie tożsamości regionalnej ${ }^{4}$.

Amerykański profesor Hiroaki Kuromiya w książce Wolność i terror w Donbasie: ukraińsko-rosyjskie pogranicze w latach 1870-1990, wysunął następujący wniosek: „W całej swojej historii Donbas był uosobieniem wolności, i ta wolność zdeterminowała jego niezwykle brutalną i okrutną historię polityczną" 5 .

Donbas, choć jego historia przeplatana jest ciągłymi walkami bardziej o prawa pracowników, niż niepodległość czy prawa osobiste, zachował swoją sławę i ducha wolności, przekory, atmosferę, w której ludzie, żyjąc w oddaleniu od upolitycznionych metropolii, uparcie bronią swojej godności oraz interesów pracowniczych. Górnicy walczyli o swoje idee, wartości, symbole, które stały na straży ich wspólnot. Mogły to być wspólnoty małe, np. baraki, i duże, jak klasa robotnicza, a nawet „Ukraina” czy „Rosja”, działały jednak w imię podobnych wartości, takich jak szacunek, stabilność i przede wszystkim godność.

Dwudziestowieczne rewolucje i zmiany ustrojowe pogłębiały nieufność mieszkańców Donbasu wobec rządzących (zarówno w Kijowie, jak i w Moskwie) oraz wywoływały masowe zamieszki.

Duży wpływ na ukształtowanie mentalności mieszkańców regionu miała ideologia radziecka. Górników uznawano za awangardę klasy robotniczej. Państwo radzieckie czyniło wysiłki na rzecz stworzenia etosu pracy $-\mathrm{z}$ jednej strony mając na celu zwiększenie jej prestiżu, a z drugiej - obronę ludzi pracy przed „wrogami” wewnętrznymi i zewnętrznymi. Donbas nazywano sercem kraju; oficjalnie nadano mu status uprzywilejowanego regionu, stanowiącego wizytówkę socjalizmu. Za czasów radzieckich nakręcono wiele filmów o górnikach, a w każdą ostatnią niedzielę sierpnia świętowano Dzień Górnika. Niegdyś zróżnicowani ludzie stali się jedną zdyscyplinowaną grupą z wysokim poczuciem

\footnotetext{
${ }^{4}$ Г. Коржов, Региональная идентичность Донбасса: генезис и тенденции развития в условиях общественной транформаиии, http://i-soc.com.ua/journal/04_Korzhov.pdf [dostęp: 20.09. 2015].

${ }^{5}$ Г. Куромія, dz. cyt., s. 510.
} 
własnej godności. Związek Radziecki nareszcie zrobił dla Donbasu to, o co walczył on od zawsze.

W 1991 roku, kiedy to Związek Radziecki uległ rozwiązaniu, przed Donbasem pojawiła się trudna decyzja. Region ten od niepamiętnych czasów był mieszanką ludności nieposiadającej jednej określonej tożsamości państwowej i przez większą część historii był częścią jednego kraju. Mimo to, aż 83\% mieszkańców Doniecka i 84\% ludności ługańskiej głosowało za uchwaleniem deklaracji niezależności Ukrainy od ZSRR ${ }^{6}$. Mieszkańcy oczekiwali, że młode państwo ukraińskie będzie troszczyło się o ich godność oraz interesy. W ich odczuciu, tak się jednak nigdy nie stało.

Do dzisiaj funkcjonują liczne mity o brudnym, brutalnym, zdeprawowanym, zapijaczonym i niewykształconym rosyjskim Donbasie. Donbasie, w którym nie mieszkają nawet prawdziwi Ukraińcy, lecz ludzie, którzy nigdy tak naprawdę nie kochali Ukrainy. Donbas jest wręcz postrzegany jako rosyjski koń trojański na Ukrainie, robiący wszystko, co w jego mocy, aby Ukraina pozostała w ścisłej zależności od Rosji. Z kolei dumny Donbas (duma jest pochodną ciężkiej codziennej pracy $\mathrm{w}$ kopalniach) w odczuciu mieszkańców regionu został potraktowany w sposób uwłaczający. Mieszkańcy Donbasu żyją w przekonaniu, że ich region „karmi Ukrainę” i że jest główną siłą ekonomiczną kraju. Stąd polityczne przywództwo Doniecka jest w ich opinii czymś logicznym i naturalnym. W regionie tym powszechne jest przekonanie, że tamtejsza ludność została najbardziej dotknięta załamaniem się gospodarki postradzieckiej w latach 90. XX w. Ponadto, mieszkańcy żyją tam w poczuciu wyrządzonej im niesprawiedliwości społecznej. Tysiące ludzi musiały pogodzić się ze zmianą swojego statusu z najwyższego w czasach Związku Radzieckiego na status „upokorzonych". Co więcej, to właśnie kwestia tego, czy państwo jest w stanie zapewnić obywatelom równość i sprawiedliwość społeczną. postrzegana jest przez mieszkańców Donbasu jako podstawowe kryterium oceny funkcjonowania kraju. Ukraina - w ich opinii - nie doceniła unikalności Donbasu, nie troszczyła się i nie dziękowała za trud włożony w pracę oraz wysokie dochody do budżetu.

Z punktu widzenia jego mieszkańców kulturową stolicą Ukrainy jest nie Lwów, lecz Charków. Mieszkańcy Donbasu, dla których jedyną prawdziwą pracą jest praca w kopalni, uważają ,zachodniaków” za leniwych. Donbaski Pragmatyzm nigdy nie zrozumiał zachodniego nacjonalizmu. Mieszkańcy zachodniej Ukrainy są postrzegani przez nich jako banderowcy oraz „niewolnicy”

\footnotetext{
${ }^{6}$ До 15-ї річниці Всеукраӥнського референдуму Документи з фондів ЦДАВО Украӥни, http:// www.archives.gov.ua/Sections/15r-V_Ref/index.php?11 [dostęp: 27.10.2015].
} 
Zachodu. Do dziś odczuwalna jest nostalgia za Związkiem Radzieckim i poczuciem godności, jakie ZSRR im oferował.

Przeplatanie się historii, kultury i gospodarki obwodów donieckiego i ługańskiego doprowadziło do nieformalnego ich zjednoczenia w skonsolidowany region o wspólnych społeczno-politycznych uwarunkowaniach. Ten proces konsolidacji przyczynił się do powstania jednej, wspólnej ideologii, tożsamości i kultury.

Większość mieszkańców Donbasu nie popierała Majdanu i nie zaakceptowała nowej władzy w Kijowie po ucieczce byłego prezydenta Wiktora Janukowycza. Początek protestów w obwodzie donieckim i ługańskim nastąpił w efekcie nasilonej propagandy $\mathrm{w}$ tym regionie, wymierzonej w idee Majdanu, a także niezręcznej polityki nowego rządu, któremu nie udało się właściwie odczytać nastrojów większości mieszkańców wschodniej Ukrainy. Pasywność mieszkańców, brak poczucia odpowiedzialności za polityczne przemiany, wreszcie zaślepienie spowodowane wojną informacyjną i związaną z nią indoktrynacją, doprowadziły do tego, że ludność Donbasu stała się podatna na hasła separatystyczne i pozytywnie odniosła się do faktu utworzenia nowych „republik”. Konflikt zbrojny $\mathrm{w}$ tym regionie zmusił ludzi do emigracji lub pozostania i, co za tym idzie, jeszcze większej izolacji od świata.

Tym samym, wydarzenia 2014 roku stworzyły nowy rozdział w długiej historii lęków, nieufności i konfliktów istniejących między mieszkańcami Donbasu a strukturami władzy. Przyszłość tego regionu rysuje się jako trudna i niepewna. Dwuznaczny status polityczny, słaba sytuacja gospodarcza, wojna informacyjno-propagandowa i ciągłe zagrożenie rozpoczęciem nowych walk gwarantują, iż region ten jeszcze przez długi czas będzie obszarem niestabilnym i konfliktogennym. 


\section{Bibliografia}

Pieniążek P., Pozdrowienia z Noworosji, Warszawa 2015.

Studenna-Skrukwa M., Ukraiński Donbas, Poznań 2014.

Донбас. Дискусія про майбутне, http://life.pravda.com.ua/society/2015/07/27/197707/ [dostęp: 20.09.2015].

Коржов Г., Региональная идентичность Донбасса: генезис и тенденщии развития в условиях общественной транформачии, http://i-soc.com.ua/journal/04_Korzhov.pdf [dostęp: 20.09.2015].

Куромія Г., Свобода і терор на Донбасі Украӥнсько-російське прикордоння, 1870 - 1990-ті роки, tłum. Г. Корян, А. Агеєв, Київ 2002.

Майбутнє Донбасу - військова диктатура під управлінням сурковско-ахметовських ставлеників - погляд з «ДНР», http://uapress.info/uk/news/show/99352 [dostęp: 27.10.2015].

\section{Regional identity in Donbas}

The article analyzes the specificity of regional identity in Donbas. The author explains how the shared social and cultural experiences, values and similar way of living shaped the society and determined the feelings of belonging to community based on common territory, in the mentioned area. She also discusses such problems as the oligarchic model of governance which delayed the development of civil society, and the question of social inequalities which stimulated the patron-client relations. Myths and stereotypes about Donbas are used by politicians and they play an enormous role in escalating conflict between eastern and western part of Ukraine.

Keywords: regional identity, Donbas, Ukraine, migration, internationalism, myths and stereotypes 